\title{
Creating Learning Interest in the Course "Earthquake Resistant Design of Structures" using Innovative Assessment Methods
}

\author{
Meyyappan Palaniappan ${ }^{1}$, Sivapragasam Chandrasekar ${ }^{2}$ \\ ${ }^{1}$ Department of Civil Engineering, Kalasalingam Academy of Research and Education, Krishnankoil - 626126, Tamil Nadu \\ ${ }^{2}$ Department of Civil Engineering, Kalasalingam Academy of Research and Education, Krishnankoil - 626126, Tamil Nadu \\ ${ }^{1}$ meyyappan@klu.ac.in \\ ${ }^{2}$ sivapragasam@klu.ac.in
}

\begin{abstract}
It is generally a known fact that as students come to the final year of their degree programme, they get involved in many other activities which are required for defining their future career. This sometimes lead to lesser attention in teaching-learning which has adverse affects when some unavoidable important course are to be taught only in the final semester after completing all the prerequisite requirements in the preceding semesters. This paper recommends the use of a set of innovative evaluation methods like technical quiz, seminar, mini-project and research based article writing with their appropriate weightage for calculating the internal continuous assessment instead of having only single mode of written test as practiced in conventional system. A study was carried out involving 80 students of IV year Civil Engineering in the course 'Earthquake Resistant Design of Structures'. Students were asked to give seminars in which they were tested on ability to comprehensively present and communicate the technical details. The published research articles were analysed by the students to identify the newer methods and software used. Students also got to work on a mini project at a lab scale level. The slow learners and medium learners did a much better performance in conducting projects showing increased interest in the course. The study reveals that student involvement should be retained in innovative ways till the last semester of their degree programme which has many tangible and intangible advantages in enhancing the competence of the students.
\end{abstract}

Keywords: Innovative assessment, Technical quiz, Seminar, Mini project, Research based article writing, Sessional examination

\section{Meyyappan Palaniappan}

Department of Civil Engineering, Kalasalingam Academy

of Research and Education, Krishnankoil - 626126

meyyappan@klu.ac.in

\section{Introduction}

In a traditional educational system, the teaching learning process is mainly based on the teacher-centered approach, in which the teacher is the learning environment controller [A.H.Sequeria., 2012]. They will play the role of instructor in promoting the learning process without considering the learners and their interests. The current education scenario is taking swift transform from the teacher-centered approach to learner-centered approach [Nahid Shirani Bidabadi., 2016]. It is the transit time that the educators must pay attention and concentrate more towards to adopt this learner-centered approach, in order to fulfil the expectations of learners especially in the engineering stream. In the few last years, it is observed that there are huge numbers of unmotivated students in the engineering course due to the traditional education system. So they are not paying interest in the classes/labs and simply studying in the last minute for the conventional passing criteria norms [Ashish Jadhav., 2019]. Effective teaching strategies [Ahmadi Begum., 2019] are required in teaching engineering to create the interests with more activity based approach and motivating the learner to contribute fully and enthusiastically in the learning process. This also addresses the employers requirements in which the learners are expected to develop their engineering skills for acquiring knowledge, independent learning, critical/innovative thinking and effective time management etc [Mariana Durcheva., 2019]. The learning outcomes should be properly assessed with clearly stated goals and measurable objectives [Richard M. Felder., 2000]. The goals and objectives make the learners to acquire adequate knowledge, relevant skills, right attitudes and demonstration ability in the engineering subject and this could be measured with exact choice of assessment tools and evaluation criteria. It is important to design some innovative assessment tools for creating the interests in the engineering course especially in the core papers, so that they will be having more confidence in facing placement and pursuing higher studies. From that view, some innovative assessments have been planned and executed by involving 80 students of IV year civil engineering for the core course 'Earthquake Resistant 
Design of Structures'. A set of some innovative assessment methods used in the study include quiz, seminar, miniproject, sessional exam and research based article with proper evaluation criteria. Previously, this course has been taught under conventional assessment mode where normal descriptive type of written examination consists of part A ( 2 marks) and part B having (8 marks or 16 marks). Since, this kind of course don't have laboratory components for understanding the basic concepts, the entire learning process becomes a sort of dull and dry experience. The learning outcome of this course creates better competence in students for job opportunities especially in design and construction field. Considering the significance of the course, an attempt is made to impart some innovative assessment methods in order to create the learning interest.

\section{Assessment Methodology}

The innovative evaluation tools such as innovative individual assignments, technically enriched quizzes \& puzzles, mini projects, experimental based evaluation, model design/development, field report / case studies, research article based evaluation, seminars, open book test, peer evaluation, evaluation by industry persons etc are followed as best practice in 'Kalasalingam Academy of Research and Education (KARE)'. Based on the nature of the course and the year of study, the faculty members choose some of the evaluation tools for their teaching evaluation process from first year onwards. In IV year civil engineering curriculum, one of the important core course is "Earthquake Resistant Design of Structures". Since this is the only course concerning earthquake engineering, it is preferred to offered with innovative assessment schemes. This course provides the basic concepts, principles and application of seismic analysis and design of structures to resist the earthquake loads. The competence gained through this course will enable the students to take up challenging tasks in civil engineering companies and organizations. Moreover, the students should be able to act as a technical consultant to give corrective and counteractive solutions to strengthen the existing and new structures against the future earthquakes. Considering these outcomes, certain evaluation tools are chosen (Table 1) in which students are trained and evaluated to build their competence. The weightage of each tool for this course is indicated in Figure 1.

Table 1. Evaluation tools and its coverage

\begin{tabular}{|c|l|c|}
\hline S. No & \multicolumn{1}{|c|}{ Evaluation Tools } & Units covered \\
\hline 1 & Technical Quiz & I, II units \\
\hline 2 & Sessional Examination & III , IV units \\
\hline 3 & Seminar & All units \\
\hline 4 & Mini Project & II, III, IV units \\
\hline 5 & $\begin{array}{l}\text { Research based Article } \\
\text { Writing (RBA) }\end{array}$ & IV, V units \\
\hline
\end{tabular}

\section{Evaluation Criteria}

A. Technical quiz
Unlike conventional quizzes where students are asked to choose one of the four options (and which, as experience says, many students choose arbitrarily as well many a times), here quizzes are designed to test how well the students have comprehended the basic concepts.

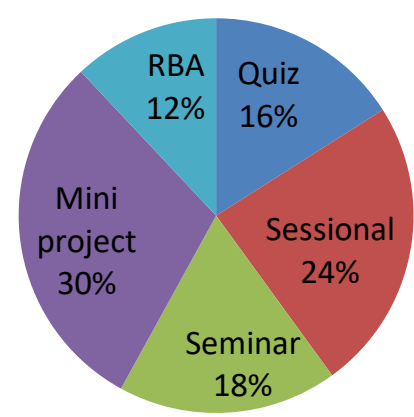

Fig. 1 Weightages of evaluation tools

Accordingly, the quizzes consisted of multiple patterns in the question such as multiple choices, true or false, fill in the blanks, match the following, pictorial identification, pictorial comments, justifying the statement, reasoning, situation based analysis etc. No negative marks for the wrong answers. Some of the samples questions are given below:

Table 2. Technical quiz sample questions

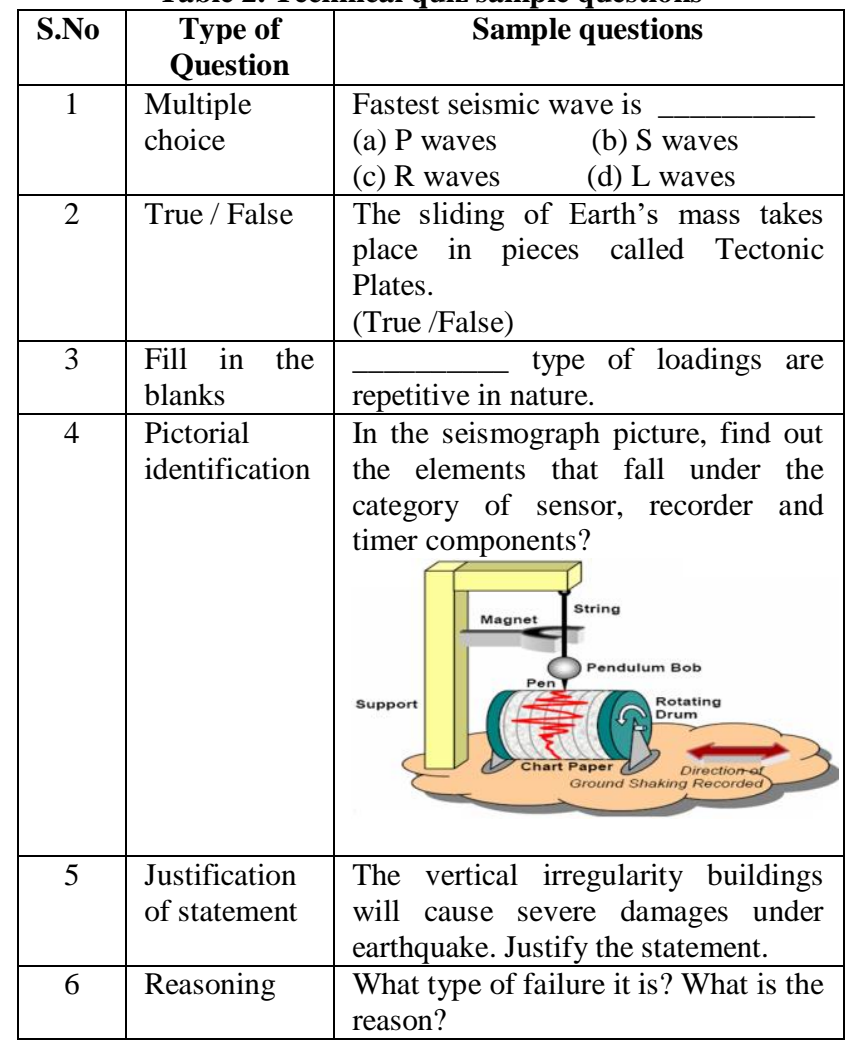




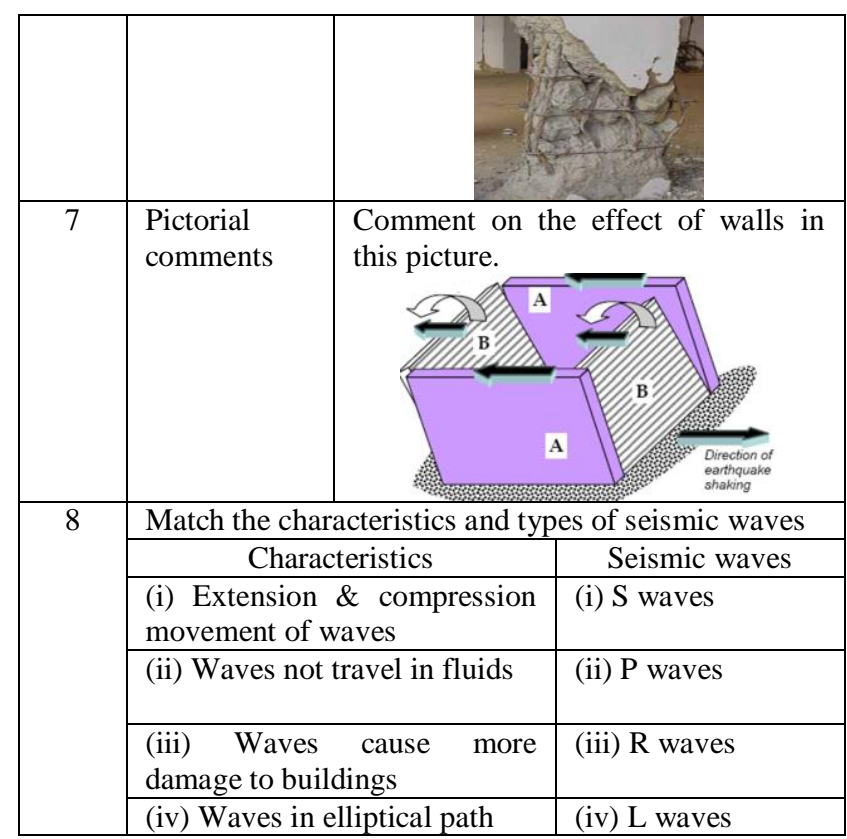

\section{B. Sessional Examination}

For this course 'Earthquake resistant design of structure', the sessional examination consisted of some innovative question patterns (unlike the conventional written exam) which include questions of linked type, requiring justification of a scenario or statement and situation/practical oriented questions. Such an approach helps the students to understand concepts better as well as given them necessary competence to apply in practical situations. Some of the sample questions of sessional exam are given in table 3 .

\begin{tabular}{|c|c|c|}
\hline S.No & $\begin{array}{l}\text { Type of } \\
\text { Question }\end{array}$ & Sample questions \\
\hline 1 & $\begin{array}{l}\text { Practical } \\
\text { oriented } \\
\text { questions }\end{array}$ & $\begin{array}{l}\text { A five storey building is planned to } \\
\text { be construct in the location of } \\
\text { Virudunagar District. After soil } \\
\text { testing, it is noticed that the soil on } \\
\text { the area is more susceptible for } \\
\text { liquefaction effects. In this case, the } \\
\text { client is approaching you requesting } \\
\text { consultation for some remedial } \\
\text { measures How will you recommend } \\
\text { the possible control measures against } \\
\text { this liquefaction? Explain them with } \\
\text { neat sketches. } \\
\text { (12 marks) }\end{array}$ \\
\hline \multirow[t]{2}{*}{2} & \multirow[t]{2}{*}{$\begin{array}{l}\text { Linked type } \\
\text { of questions }\end{array}$} & (i) $\begin{array}{l}\text { Determine the base shear for a } \\
\text { four storey commercial } \\
\text { building of SMRF type having } \\
\text { the plan dimensions } 32 \mathrm{~m} \mathrm{x} 32 \\
\text { m with the storey height } 3.5 \mathrm{~m} \text {, } \\
\text { resting on soft soil located in } \\
\text { the region of New Delhi. } \\
\text { (8 marks) }\end{array}$ \\
\hline & & $\begin{array}{l}\text { How will you design the beam } \\
\text { elements and column elements } \\
\text { for the building in question } \\
\text { no.(i) to resist earthquakes as } \\
\text { per IS } 13920 \text { codal provisions? }\end{array}$ \\
\hline
\end{tabular}

\begin{tabular}{|c|l|l|l|}
\hline & & & \multicolumn{1}{|c|}{ (12 marks) } \\
\cline { 2 - 3 } & (iii) & $\begin{array}{l}\text { Calculate the lateral force as } \\
\text { per IS 1893:2002 codal } \\
\text { provisions for building as } \\
\text { described in question no. (i). } \\
\text { Draw its storey wise } \\
\text { distribution pattern. (10 marks) }\end{array}$ \\
\hline 3 & $\begin{array}{l}\text { Justifying } \\
\text { questions }\end{array}$ & $\begin{array}{l}\text { 'T' Shaped plan of buildings are very } \\
\text { detrimental against the earthquakes. } \\
\text { Justify this statement with relevant } \\
\text { descriptions. (6 marks) }\end{array}$ \\
\hline 4 & $\begin{array}{l}\text { Situation } \\
\text { oriented } \\
\text { questions }\end{array}$ & $\begin{array}{l}\text { If the building is to be constructed on } \\
\text { the slopy ground, what is the design } \\
\text { strategy to be adopted to avoid } \\
\text { twisting failure? (5 marks) }\end{array}$ \\
\hline
\end{tabular}

\section{Seminar}

Seminars will test the students comprehension of the course as well as their ability to effectively communicate the same through use of statistical data and graphical/pictorial representation. The students were asked to give individual seminar for 15 minutes duration on any of the case study of previous earthquake disaster in the world. The seminar content (slides) should contain introduction of the earthquake, design requirements, damage observation on various buildings, conclusion and lessons learnt from that earthquake. The students were assessed on the quality of technical content, visual aids (Clarity) speaking ability, viva and a brief report, the weightage of marks of each of which is shown in Table 4.

Table 4. Seminar evaluation criteria

\begin{tabular}{|c|l|c|}
\hline S. No & Description. & Marks \\
\hline 1 & Quality of the technical content & 30 \\
\hline 2 & Visual aids (Slides, text, images) & 25 \\
\hline 3 & Speaking ability & 25 \\
\hline 4 & Viva & 10 \\
\hline 5 & Seminar Report & 10 \\
\hline 6 & Total & 100 \\
\hline
\end{tabular}

In the end outcome, the student can able to engage in the discussion of an academic topic to achieve a goal of getting better insight of the subject through variety of substances.

\section{Mini project}

Mini project helps the students to explore, strengthen and sharpen the understanding of fundamentals through practical application of theoretical concepts. Problem descriptions were well defined and students were asked to perform analysis considering various factors. Table 5 lists some of the sample mini projects:

Table 5. Sample mini project

\begin{tabular}{|c|l|l|}
\hline S. No & $\begin{array}{l}\text { Description of mini } \\
\text { project }\end{array}$ & Outcomes of this project \\
\hline 1 & $\begin{array}{l}\text { Seismic analysis of } \\
\text { Building with infill } \\
\text { wall and without } \\
\text { infill wall in high } \\
\text { seismic zone }\end{array}$ & $\begin{array}{l}\text { How the presence of infill } \\
\text { wall will influence the } \\
\text { buildings in terms of its } \\
\text { seismic response especially } \\
\text { under high seismic prone } \\
\text { areas? }\end{array}$ \\
\hline 2 & Seismic analysis of & How the seismic response of \\
\hline
\end{tabular}




\begin{tabular}{|c|c|c|}
\hline & $\begin{array}{l}\text { buildings under } \\
\text { different zones }\end{array}$ & $\begin{array}{l}\text { a building varies under } \\
\text { different seismic zones (Low, } \\
\text { Moderate, Severe and Very } \\
\text { severe) on different soil } \\
\text { conditions (Hard, Medium } \\
\text { and Soft). }\end{array}$ \\
\hline 3 & $\begin{array}{l}\text { Seismic performance } \\
\text { of RC structures with } \\
\text { and without setbacks }\end{array}$ & $\begin{array}{l}\text { By different structural } \\
\text { configurations of vertical } \\
\text { irregularity, what would be } \\
\text { the effect in terms of seismic } \\
\text { performance on those } \\
\text { buildings? }\end{array}$ \\
\hline 4 & $\begin{array}{l}\text { Effect of soil } \\
\text { structure interaction } \\
\text { on seismic design of } \\
\text { building }\end{array}$ & $\begin{array}{l}\text { What would be the effect on } \\
\text { the seismic response of the } \\
\text { buildings if the soil is } \\
\text { considered along with the } \\
\text { structure? }\end{array}$ \\
\hline 5 & $\begin{array}{l}\text { Effect of soft storey } \\
\text { on symmetrical and } \\
\text { asymmetrical RCC } \\
\text { buildings under } \\
\text { seismic load }\end{array}$ & $\begin{array}{l}\text { How the symmetrical and } \\
\text { asymmetrical type of RCC } \\
\text { buildings (with and without } \\
\text { soft storey configurations) } \\
\text { will behave under seismic } \\
\text { loading. What would be the } \\
\text { variation in the seismic } \\
\text { response levels? }\end{array}$ \\
\hline
\end{tabular}

The evaluation criterion for the mini project activity is shown in table 6.

Table 6. Mini project evaluation criteria

\begin{tabular}{|c|c|c|c|}
\hline Description & $\begin{array}{c}\text { Good } \\
\text { (Marks above } \\
75 \%) \\
\end{array}$ & $\begin{array}{c}\text { Average } \\
\text { (Marks } \\
40 \% \text { to } 74 \% \text { ) }\end{array}$ & $\begin{array}{c}\text { Poor } \\
\text { (Marks less } \\
\text { than 40\%) }\end{array}$ \\
\hline $\begin{array}{l}\text { Technical } \\
\text { content }\end{array}$ & $\begin{array}{l}\text { Is fully clear } \\
\text { to apply the } \\
\text { design } \\
\text { principles in } \\
\text { analysing the } \\
\text { given case } \\
\text { with proper } \\
\text { justification } \\
\text { from relevant } \\
\text { codes }\end{array}$ & $\begin{array}{l}\text { Is able to } \\
\text { apply the } \\
\text { design } \\
\text { principles and } \\
\text { analyse the } \\
\text { given case, } \\
\text { though not } \\
\text { very clear } \\
\text { about codal } \\
\text { recommendati } \\
\text { ons. }\end{array}$ & $\begin{array}{l}\text { Makes } \\
\text { mistakes in } \\
\text { the } \\
\text { understanding } \\
\text { of } \\
\text { fundamental } \\
\text { principles }\end{array}$ \\
\hline $\begin{array}{l}\text { Report } \\
\text { preparation }\end{array}$ & $\begin{array}{l}\text { Is able to } \\
\text { present a fully } \\
\text { structured } \\
\text { report with } \\
\text { relevant tables } \\
\text { and figures }\end{array}$ & $\begin{array}{l}\text { Is able to } \\
\text { bring all the } \\
\text { details but } \\
\text { structured } \\
\begin{array}{l}\text { approach is } \\
\text { missing. }\end{array}\end{array}$ & $\begin{array}{l}\text { Is not able to } \\
\text { clearly put the } \\
\text { thoughts and } \\
\text { work done }\end{array}$ \\
\hline Team work & $\begin{array}{l}\text { All the } \\
\text { members } \\
\text { involve at all } \\
\text { the level with } \\
\text { regular } \\
\text { meetings and } \\
\text { discussion }\end{array}$ & $\begin{array}{l}\text { All the } \\
\text { members } \\
\text { participate in } \\
\text { the design } \\
\text { process but is } \\
\text { not planned } \\
\text { regularly. }\end{array}$ & $\begin{array}{l}\text { Not all the } \\
\text { members } \\
\text { participate. }\end{array}$ \\
\hline $\begin{array}{l}\text { Submission } \\
\text { of Report }\end{array}$ & $\begin{array}{l}\text { Submitted } \\
\text { before } \\
\text { deadline }\end{array}$ & $\begin{array}{l}\text { Submitted } \\
\text { after deadline }\end{array}$ & Not submitted \\
\hline
\end{tabular}

\section{E. Research Based Article Writing}

Although the basic design principles do not change, in the practical implementation of that and the issues faced thereof, active researches are undertaken worldwide. It is necessary for the students to get a clearer picture on how engineers and researchers propose practical solutions to challenging issues. With this purpose, research article based evaluation tool is assigned for this course as one of the evaluation methods. The students were asked to take 2 research papers in the topics related to their syllabus The suitable guidelines were framed to assist the students to think from the research point of view (Table 7). With a sample research paper, first the course mentor thoroughly explained how to write down the report, since this was a new experience to the students.

Table 7. Research article based evaluation guidelines

\begin{tabular}{|c|c|c|}
\hline S. No & Description & Weightage \\
\hline \multicolumn{3}{|c|}{ Part I } \\
\hline 1 & $\begin{array}{l}\text { Re-write in your words, the structure of } \\
\text { this research paper clearly bringing out } \\
\text { the basic emphasis placed in the } \\
\text { research. }\end{array}$ & \multirow{3}{*}{$20 \%$} \\
\hline 2 & $\begin{array}{l}\text { Evaluate how the authors have taken } \\
\text { into consideration the works reported by } \\
\text { previous researchers, how the analysis is } \\
\text { done on the current status and } \\
\text { identification of the research need. }\end{array}$ & \\
\hline 3 & $\begin{array}{l}\text { What specific research objectives are } \\
\text { addressed? }\end{array}$ & \\
\hline \multicolumn{3}{|c|}{ Part II } \\
\hline 4 & $\begin{array}{l}\text { Write in your own words about methods } \\
\text { and procedures used in this paper, how } \\
\text { are they different from what is studied in } \\
\text { the class and what are the assumptions } \\
\text { in which these proposed methods are } \\
\text { based? }\end{array}$ & $20 \%$ \\
\hline \multicolumn{3}{|c|}{ Part III } \\
\hline 5 & $\begin{array}{l}\text { Comment on whether the tables and } \\
\text { figures (if any) are well organized and } \\
\text { suitably reflect the results and } \\
\text { discussion part? }\end{array}$ & \multirow[t]{2}{*}{$20 \%$} \\
\hline 6 & $\begin{array}{l}\text { Summarize how the authors have given } \\
\text { scientific justification for the results } \\
\text { obtained. }\end{array}$ & \\
\hline \multicolumn{3}{|c|}{ Part IV } \\
\hline 7 & $\begin{array}{l}\text { Highlight the major findings in the } \\
\text { research paper }\end{array}$ & \multirow{3}{*}{$20 \%$} \\
\hline 8 & $\begin{array}{l}\text { Are there any recommendations for the } \\
\text { future work? }\end{array}$ & \\
\hline 9 & $\begin{array}{l}\text { In what way references/bibliography are } \\
\text { present in this research paper. }\end{array}$ & \\
\hline \multicolumn{3}{|c|}{ Part V } \\
\hline 10 & $\begin{array}{l}\text { Bring out the new concepts } / \\
\text { methods/techniques/terminologies learnt } \\
\text { from this research paper which is } \\
\text { beyond the syllabus? }\end{array}$ & $20 \%$ \\
\hline
\end{tabular}


Table 8 shows the statistics of students in different range of scores for the various evaluation tools. A score less than 40 is considered not satisfactory, while scores above 90 are considered as excellent. It is observed (from Figure 2), that except in sessional exam assessment, in all other assessments, the students performance have been better. Even in sessional exam, only $5 \%$ of the students secured less than 40 marks. In almost all the assessment methods, most of the students were in the category of good (70-80) to very good (80-90). In seminar based assessment, the performance of the students is found to be moderate with 31 students in the range of 51-60 marks. This can be attributed to the fact that most of these students come from rural background, and they didn't have a prior experience of such assessments. However, the student feedback indicates that the students have actually improved in their competence compared to their default situation.

Table 8. Results of evaluation methods

\begin{tabular}{|c|c|c|c|c|c|c|c|}
\hline Tools / Marks range & $\frac{8}{\frac{8}{a}}$ & $\frac{a}{\infty}$ & $\stackrel{\infty}{\stackrel{\infty}{1}}$ & $\frac{7}{6}$ & $\frac{8}{i n}$ & $\underset{7}{\stackrel{8}{7}}$ & $\underset{v}{\stackrel{P}{v}}$ \\
\hline Technical Quiz (TQ) & 0 & 11 & 13 & 34 & 16 & 6 & 0 \\
\hline $\begin{array}{l}\text { Sessional } \\
\text { Examination (SE) }\end{array}$ & 2 & 6 & 18 & 27 & 10 & 13 & 4 \\
\hline Seminar $(\mathrm{S})$ & 1 & 12 & 7 & 17 & 31 & 13 & 0 \\
\hline Mini project (MP) & 2 & 23 & 40 & 15 & 0 & 0 & 0 \\
\hline $\begin{array}{l}\text { Research based article } \\
\text { writing (RBA) }\end{array}$ & 4 & 42 & 34 & 0 & 0 & 0 & 0 \\
\hline
\end{tabular}

It is observed that from the feedback that the students have to concentrate more in enriching the relevant technical content, speaking ability and answering to the viva questions. This assessment also gave an opportunity for them to enhance their communication by observing others presentation and the required inputs from the course mentor In research based article, all the students did their exercise in an interesting manner with full involvement. Even the so-called so learner students did well in this assessment. This indicates that the assessment was able to inspire research interest in students.

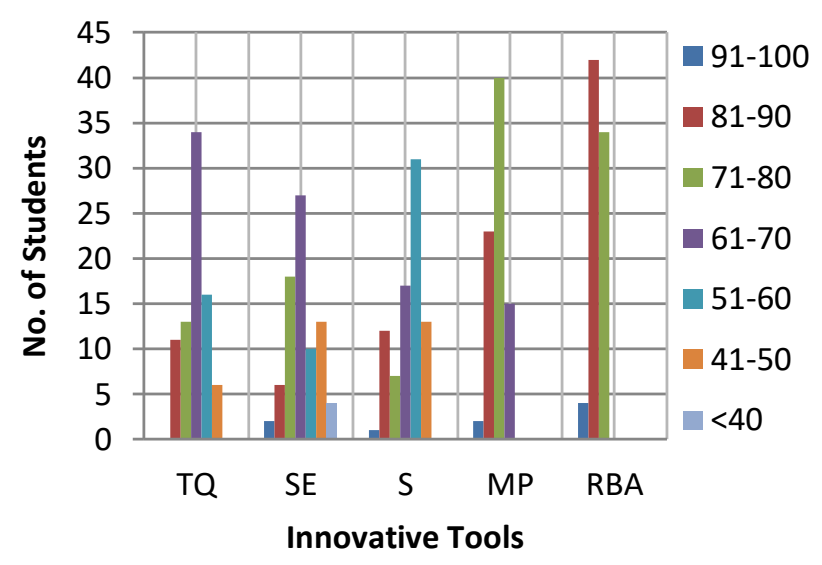

Fig. 2 Evaluation Results

They learnt how to read a published literature how to observe the notable things in the particular the paper, how to correlate the research outcomes to the research objectives, how to cite a paper and at the last they learnt how to prepare a full research paper. This assessment method will especially help students to convert their projects into a research paper, as reflected from the student feedback response.

\begin{tabular}{|c|c|c|c|c|c|c|}
\hline Q. No & Feedback questions & 1 & 2 & 3 & 4 & 5 \\
\hline 1 & $\begin{array}{l}\text { I had an opportunity to } \\
\text { improve my communication } \\
\text { and presentation skills during } \\
\text { seminar }\end{array}$ & & & & & \\
\hline 2 & $\begin{array}{l}\text { Technical quiz has helped me a } \\
\text { lot to enrich my course content }\end{array}$ & & & & & \\
\hline 3 & $\begin{array}{l}\text { In mini-project, the problem } \\
\text { description and objectives are } \\
\text { very clear in arriving at the end } \\
\text { outcomes }\end{array}$ & & & & & \\
\hline 4 & $\begin{array}{l}\text { Learnt to present the results in } \\
\text { a comparative way with } \\
\text { graphical representations } \\
\text { during mini project }\end{array}$ & & & & & \\
\hline 5 & $\begin{array}{l}\text { The research based article } \\
\text { writing created a platform to } \\
\text { write a research oriented paper. }\end{array}$ & & & & & \\
\hline 6 & $\begin{array}{l}\text { Through the practical } \\
\text { situation oriented question, I } \\
\text { am able to relate the skills and } \\
\text { its application. }\end{array}$ & & & & & \\
\hline 7 & $\begin{array}{l}\text { In overall, the innovative } \\
\text { evaluation tools helped a lot in } \\
\text { understanding the concept and } \\
\text { created interest in this course. }\end{array}$ & & & & & \\
\hline
\end{tabular}

1-Strongly agree; 2-Agree; 3-OK; 4-Disagree; 5-Strongly disagree In quiz, mostly the students are in the range of 61-70 marks. This indicated that the students need more training in understanding and applying of specific concepts learnt. However, it is noteworthy to observe that even the slow learners developed better understanding of the concepts than their usual performance in the conventional written exams. In mini project activity, students have done well 
which is clearly reflected in their score, mostly varied from 61 - 90 (76 students). With this assessment method, students also learnt how to present results as well as write a good technical report.

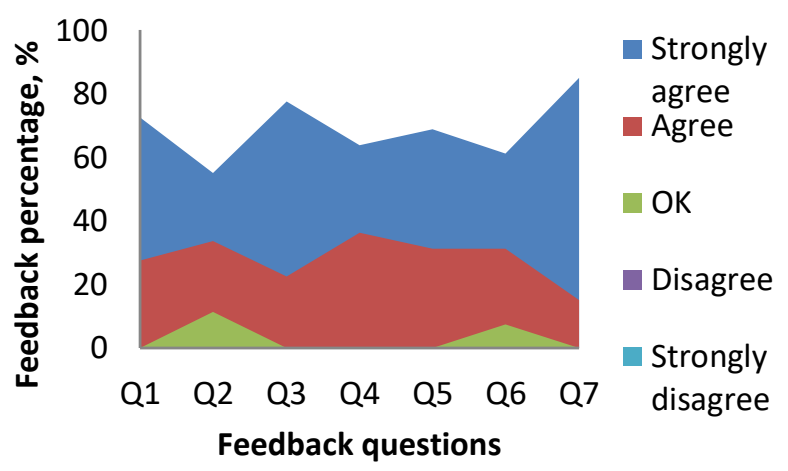

Fig.3 Feedback analysis

Table 9 shows the feedback questionnaire to be collected at the end of the course about their learning experience in this subject. Figure 3 shows the graphical representation of the summary of the students feedback based on the feedback questionnaire which clearly indicates $90 \%$ of the students are satisfied with this type of evaluation methods. Moreover, this shows that students could improve considerably in their practical skills and competence. In summary, it can be said that activity based learning and evaluation will create more interest as well as impart competence in learning and applying the principles in core courses like earthquake resistant design of structures.

\section{Conclusion}

A set of some innovative assessment methods such as quiz, seminar, mini-project, sessional exam and research based article with proper evaluation criteria are proposed and implemented for the assessing the course 'Earthquake Resistant Design of Structures'. Except for sessional exam, the students did much better in all the other assessments, but that was expected as non-conventional question pattern are new to the students. Research based article based assessment helped the students significantly in improving their research aptitude. Seminars helped the students to comprehend the technical concepts and develop competence to present both through oral as well as written communication. In the mini-project, the students learnt how to take the principles to practical application of real situation utilizing the codal provisions. They also learnt the skill of writing the project report, formatting and comparative discussions. The study reveals that activity based learning and evaluation will create more interest in learning core courses in the engineering discipline. The only challenge is in terms of time constraints, but that is managed by students during the 2nd and 3rd sessional exams as well as during weekends.

\section{References}

1. Nahid Shirani B, Ahmmadreza Nasr I, Amir Rouhollahi and Roya Khalili (2016) Effective Teaching Methods in Higher Education: Requirements and Barriers. Journal of Advances in Medical Education \& Professionalism, 4(4), 170-178.

2. Sequeira A.H (2012). Introduction to Concepts of Teaching and Learning, SSRN, doi.org/10.2139/ssrn.2150166.

3. Nurul Asyikin Mohamed Radzi and Suhaila Sulaiman (2018) Measuring Student's Interest towards Engineering in Technical School: A Case Study. Journal of Technology and Science Education, 8(4), 231-237.

4. Ahmadi Begum (2019) Innovative and Effective Teaching Methods for Engineering Students. International Journal of Humanities and Social Science, 6(1), 1-5.

5. Kothari, M. R. (1998), Types of Research, in Research Methodology 5th Edition, HAP Publication, New Delhi pp 145-190.

6. Ashish Jadhav (2019), Engineering and Stream Foundation Courses for Motivating the Students $1^{\text {st }}$ Edition, IOR International Press, Coimbatore pp10-13. 